\title{
An untranslated insertion variant in the uncoupling protein 2 gene is not related to body mass index and changes in body weight during a 26-year follow-up in Danish Caucasian men
}

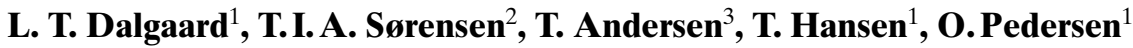 \\ ${ }^{1}$ Steno Diabetes Center, Gentofte, Copenhagen, Denmark \\ ${ }^{2}$ Danish Epidemiology Science Centre at the Institute of Preventive Medicine, Copenhagen University Hospital, Denmark \\ ${ }^{3}$ Roskilde County Hospital, Roskilde, Denmark
}

\section{Abstract}

Aims. Associations between a 45 bp 3 'untranslated insertion polymorphism in the uncoupling protein 2 (UCP2) gene and both body mass index (BMI) and sleeping metabolic rate have previously been reported. We investigated the impact of this polymorphism on BMI and long-term body weight changes.

Methods. The allelic frequency of the UCP2 insertion variant was determined in a cohort of 744 obese Danish Caucasian men who had a BMI of at least $31 \mathrm{~kg} /$ $\mathrm{m}^{2}$ at the draft-board examinations and a randomly selected control cohort consisting of 872 draftees. Follow-up measurements of BMI were done on average 26 years after the draft-board examinations.

Results. The prevalence of the insertion allele was $30.4 \%$ (95\% confidence interval: $28.0-32.8 \%$ ) among the obese and $29.6 \%(27.4-31.8 \%)$ in the control group $(p=0.6)$. In a lean group selected as the
354 subjects with a BMI less than $25 \mathrm{~kg} / \mathrm{m}^{2}$ at 46 years of age from the control group, the frequency of insertion allele was $29.0 \%(27.2-30.8 \%)(p=0.5$ compared with the obese cohort). The BMI at the ages of 20 and 46 years did not differ between genotypes either in the obese or the control group. Similarly, the changes in BMI/year between examinations at 20 and 46 years of age did not differ between genotypes in either group.

Conclusion/interpretation. In a large group of Danish Caucasian men we found no association between a 3 'untranslated insertion polymorphism in the $U C P 2$ gene and obesity. Neither did we identify a relation between this variant and BMI changes during adult age. [Diabetologia (1999) 42: 1413-1416]

Keywords Uncoupling protein 2, UCP2, obesity, body mass index, polymorphism, genetics, insertion, deletion.
Uncoupling Protein 2 (UCP2) belongs to a family of mitochondrial transporters which are thought to uncouple the oxidative phosphorylation by increasing the proton conductance of the inner mitochondrial membrane [1]. This leads to heat production rather than energy storage. The UCP2 gene is a candidate gene for obesity as its decreased function or expression might reduce energy expenditure and thereby increase the propensity to store energy as fat. In mice

Received: 21 July 1999 and in revised form: 14 September 1999

Corresponding author: L. T. Dalgaard, Steno Diabetes Centre, Niels Steensens Vej 2, DK-2820 Gentofte, Denmark

Abbreviations: UCP2, Uncoupling protein 2; 3 'UTR, 3 'untranslated region. quantitative trait loci for obesity coincide with the genomic location of the $U C P 2$ gene on chromosome 7 [2] and in humans linkage between the UCP2 locus on chromosome $11 \mathrm{q} 13$ and resting metabolic rate has been reported [3]. The $U C P 2$ is expressed in various tissues with white adipose tissue and skeletal muscle as major sites of expression [1]. The expression of the $U C P 2$ gene is increased in an obesity-resistant mouse strain, C57BL A/J, compared with the obesity-prone strain $\mathrm{C} 57 \mathrm{BL} 6 / \mathrm{J}$ [4]. It has also been reported that the amount of $U C P 2 \mathrm{mRNA}$ is decreased in adipose tissue and skeletal muscle of human obese subjects [5, $6]$. The coding regions of the $U C P 2$ gene contain, however, little variability. Only one common genetic variant, Ala/Val 55, has been identified and it was not associated with obesity in several studies $[7,8]$. 
Table 1. Comparison of the body mass index of insertion homozygous (II), heterozygous (ID) and wild-type (DD) genotypes of the 3'UTR variant in the UCP2 gene according to study group and age

\begin{tabular}{|c|c|c|c|c|c|}
\hline Genotype & $I I$ & $p$ & $I D$ & $p$ & $D D$ \\
\hline $\begin{array}{l}\text { Obese subjects } \\
n \\
\text { BMI at mean age } 20 \text { years } \\
\text { BMI at mean age } 46 \text { years } \\
\Delta \mathrm{BMI}\left(\mathrm{kg} \cdot \mathrm{m}^{-2} \cdot \text { year }^{-1}\right)\end{array}$ & $\begin{array}{r}80 \\
32.7(2.6) \\
34.7(6.0) \\
0.3(1.0)\end{array}$ & $\begin{array}{l}1.00 \\
0.81 \\
0.68\end{array}$ & $\begin{array}{r}293 \\
32.4(2.3) \\
34.8(7.3) \\
0.3(1.0)\end{array}$ & $\begin{array}{l}0.11 \\
0.37 \\
0.61\end{array}$ & $\begin{array}{c}371 \\
32.6(2.6) \\
35.3(8.2) \\
0.3(0.9)\end{array}$ \\
\hline $\begin{array}{l}\text { Random control subjects } \\
n \\
\text { BMI at mean age } 20 \text { years } \\
\text { BMI at mean age } 46 \text { years } \\
\Delta \text { BMI }\left(\mathrm{kg} \cdot \mathrm{m}^{-2} \cdot \text { year }^{-1}\right)\end{array}$ & $\begin{array}{c}76 \\
21.3(4.4) \\
26.2(5.7) \\
0.5(0.6)\end{array}$ & $\begin{array}{l}0.14 \\
0.26 \\
0.77\end{array}$ & $\begin{array}{r}364 \\
21.5(3.0) \\
25.7(4.4) \\
0.5(0.4)\end{array}$ & $\begin{array}{l}0.25 \\
0.77 \\
0.99\end{array}$ & $\begin{array}{r}432 \\
21.1(2.7) \\
25.7(4.7) \\
0.5(0.4)\end{array}$ \\
\hline $\begin{array}{l}\text { Lean control subjects } \\
n \\
\text { BMI at mean age } 20 \text { years } \\
\text { BMI at mean age } 46 \text { years } \\
\Delta \text { BMI }\left(\mathrm{kg} \cdot \mathrm{m}^{-2} \cdot \text { year }^{-1}\right)\end{array}$ & $\begin{array}{c}28 \\
19.7(2.0) \\
23.0(2.4) \\
0.5(0.3)\end{array}$ & $\begin{array}{l}0.35 \\
0.14 \\
0.84\end{array}$ & $\begin{array}{c}149 \\
20.4(2.1) \\
23.3(2.2) \\
0.3(0.3)\end{array}$ & $\begin{array}{l}0.38 \\
0.75 \\
0.68\end{array}$ & $\begin{array}{r}177 \\
20.3(2.0) \\
23.2(2.3) \\
0.3(0.3)\end{array}$ \\
\hline
\end{tabular}

Data are medians (interquartile range). $P$ values compare the insertion/insertion (II) or the insertion-deletion (ID) genotype to the deletion-deletion $(D D)$ genotype in the 3'UTR variant in the UCP 2 gene using Mann-Whitney rank sum test for the obese and lean control study groups and Student's $t$ test for the random control study group
A prevalent $45 \mathrm{bp}$ insertion polymorphism is present in the 3 'untranslated region ( $\left.3^{\prime} \mathrm{UTR}\right)$ of the UCP2 gene 158 bp downstream of the stop codon [7, 9]. The heterozygotic insertion-deletion genotype (ID) was found to be associated with increased sleeping metabolic rate and 24-h energy expenditure and with lower BMI in Pima Indians [9]. Furthermore, a South Indian population shows association between increased BMI and the homozygotic insertion genotype (II) [10]. In contrast, a study in French subjects found no association between morbid obesity and this polymorphism [7].

The objective of our study was to investigate whether the 3'UTR insertion-deletion polymorphism was associated with juvenile-onset obesity in Danish Caucasian men and furthermore to examine the impact of this variant on changes in BMI over time in two large samples of military draftees. One sample comprised 791 obese Danish Caucasian men who had a BMI of at least $31 \mathrm{~kg} / \mathrm{m}^{2}$, and the other 915 randomly chosen male control subjects who had a BMI less than $31 \mathrm{~kg} / \mathrm{m}^{2}$ at the draft board examination.

\section{Subjects and methods}

Subjects. The association study was carried out in two study groups selected from young Danish Caucasian men, who at the age of 19 or 20 years (inter-quartile range: 19-20 years) were examined at the draft board, where height and weight were measured. The 791 subjects with a BMI of at least $31 \mathrm{~kg}$ / $\mathrm{m}^{2}$ were selected to comprise the obese group. As a random control group, 915 subjects were selected at random as every two hundredth from the same population. As part of the Copenhagen City Heart Study Programme the study groups were re-examined in 1992-1994 when the subjects were on av- erage 46 years old (between 34 and 75 years of age) [11]. The mean time interval between examinations was 26 years (range 15-50 years). Genomic DNA was obtained from blood samples drawn at the second examination. For statistical analysis a lean control group $(n=354)$ was constructed comprising only the control subjects with a BMI less than $25.0 \mathrm{~kg} / \mathrm{m}^{2}$ at the second examination. The BMI at the mean age of 20 and 46 years and the average body weight increase per year between examinations are listed in Table 1 . Informed consent was obtained from all subjects before participation. The study was approved by the ethics committee of Copenhagen and was in accordance with the principles of the Declaration of Helsinki II.

Methods. Genotyping of the ins/del polymorphism was done with PCR using the following primers: 5 '-CAGTGAGGGAA GTGGAGG-3' and 5'-GGGGCAGGACGAAGATTC-3'. The primers amplify a product of $457 \mathrm{bp}$ (insertion allele) or 412 bp (deletion allele) [9]. Polymerase chain reaction amplification was carried out in a volume of $25 \mu \mathrm{l}$ containing $100 \mathrm{ng}$ genomic DNA, $1 \times$ PCR-buffer, $0.2 \mu \mathrm{mol} / 1$ of each primer, $0.2 \mathrm{mmol} / 1 \mathrm{dNTP}, 2.0 \mathrm{mmol} / 1 \mathrm{MgCl}_{2}$ and 0.313 unit Amplitaqpolymerase (Perkin Elmer, Foster City, Calif., USA). The cycling programme was an initial denaturation at $94^{\circ} \mathrm{C}$ for 3 min followed by 35 cycles of denaturation at $94^{\circ} \mathrm{C}$ for $30 \mathrm{~s}$, annealing at $65^{\circ} \mathrm{C}$ for $30 \mathrm{~s}$, and elongation at $72^{\circ} \mathrm{C}$ for $30 \mathrm{~s}$ with a final elongation step at $72^{\circ} \mathrm{C}$ for $5 \mathrm{~min}$ using a GeneAmp 9600 thermal cycler (Perkin Elmer). The PCR-products were resolved on a $3 \%$ agarose gel.

Statistical analysis. Data analysis was restricted to 744 of 791 obese subjects and 872 of 915 of the control subjects due to lack of either DNA or PCR-product. Chi-squared analysis was done to test for differences in allele frequencies between groups. A Students $t$ test or a general linear model with age as covariant and the genotype as fixed factor was used when continuous variables were normally distributed. Otherwise the Mann-Whitney rank sum test was applied. Data are given as mean (SD) or median (inter-quartile range). A $p$ value less than 0.05 was considered significant. All analyses were done using Statistical Package for Social Science (SPSS) for Windows version 9 . 
Table 2. Allele and genotype frequencies in the study groups of the 3'untranslated insertion-deletion polymorphism in the uncoupling protein 2 gene

\begin{tabular}{|c|c|c|c|c|c|}
\hline & & Insertion allele & Genotype & & \\
\hline & & $I$ & II & $I D$ & $D D$ \\
\hline Obese subjects & $\begin{array}{l}n \\
(\%(95 \% \mathrm{CI}))\end{array}$ & $\begin{array}{l}453 \\
(30,4 \%(28.1-32.8 \%))\end{array}$ & $\begin{array}{l}80 \\
(10.8 \%)\end{array}$ & $\begin{array}{l}293 \\
(39.4 \%)\end{array}$ & $\begin{array}{l}371 \\
(49.9 \%)\end{array}$ \\
\hline Random control subjects & $\begin{array}{l}n \\
(\%(95 \% \mathrm{CI}))\end{array}$ & $\begin{array}{l}516 \\
(29.6 \%(27.4-31.8 \%))\end{array}$ & $\begin{array}{l}76 \\
(8.7 \%)\end{array}$ & $\begin{array}{l}364 \\
(41.7 \%)\end{array}$ & $\begin{array}{l}432 \\
(49.5 \%)\end{array}$ \\
\hline Lean control subjects & $\begin{array}{l}n \\
(\%(95 \% \mathrm{CI}))\end{array}$ & $\begin{array}{l}205 \\
(29.0 \%(27.2-30.8 \%))\end{array}$ & $\begin{array}{l}28 \\
(7.9 \%)\end{array}$ & $\begin{array}{l}149 \\
(42.1 \%)\end{array}$ & $\begin{array}{l}177 \\
(50.0 \%)\end{array}$ \\
\hline
\end{tabular}

' $I$ ' denotes the insertion allele, ' $D$ ' denotes the deletion allele. Data are given as numbers and percentages. For the frequency of the insertion allele $(I)$ the $95 \%$ confidence intervals are also listed

\section{Results}

The allelic frequency of the insertion allele of the 3 'UTR polymorphism in the UCP2 gene was $30.4 \%$ (95\% confidence interval: $28.0-32.8 \%$ ) among the obese subjects and $29.6 \%(27.4-31.8 \%)$ among the randomly selected control subjects (Table 2). The frequency of the insertion allele in a lean control group was $29.0 \%(27.2-30.8 \%)$. There was no difference in allele frequencies of the insertion allele between the obese and the control group $\left(\chi^{2}=0.28, p=0.6\right)$, or between the obese cohort and the lean control group $\left(\chi^{2}=0.5, p=0.5\right)$ (Table 2). The genotypes observed were in Hardy-Weinberg equilibrium. No differences in genotype frequencies were observed among the obese and lean groups. The BMI at the mean age of 20 and 46 years were similar in the subjects carrying the insertion-insertion (II) genotype, the insertion-deletion (ID) genotype and the deletion-deletion $(D D)$ genotype within the obese, random control and lean control group (Table 1). There was no difference between genotypes when considering increase in BMI/year between examinations (Table 1). It is possible that the effect of the insertion polymorphism could be age-dependent. When examining the random control group for the influence of the 3 'UTR polymorphism on the BMI at the second examination with age as covariate, there was, however, no effect of the polymorphism $(p=0.6)$.

\section{Discussion}

We have examined whether a 3 'UTR insertion polymorphism in the $U C P 2$ gene is associated with obesity or body weight changes in a large cohort of Danish Caucasian men. The prevalence of the insertion variant was equal between the obese group and the control group. In both groups there were no differences in indices of body fatness indirectly estimated as BMI between subjects carrying $I I, I D$ and $D D$ genotypes. Increase in BMI/year showed no difference between carriers of different genotypes either in the ob- ese or in the control cohort. Several reasons can be suggested to explain the discrepancies between various reports elucidating the potential role of the 3'UTR insertion. The power of our study to detect an increase of BMI of $11 \%$ between insertion homozygotes $(I I)$ and wild type $(D D)$ subjects as observed in Pima Indians above the age of 45 years [9] is above $99 \%$ in the total sample as well as in sub-groups. It is therefore unlikely that an association of obesity with this variant exists in the Danish Caucasian population. The South Indian study [10] included mainly women and our study consisted exclusively of men because in Denmark draft board examination is mandatory only for men. Therefore, a sex difference cannot be excluded. Furthermore, there might be differences in the impact of this polymorphism in various ethnic populations because of different genetic background between Pima Indians, South Indians and European Caucasians. This interpretation is supported by the findings of no association between the presence of the 3'UTR insertion allele and obesity in French Caucasians of both sexes [7].

Our primary hypothesis was that the 3 'UTR insertion had an effect on early-onset obesity. We have also tested the alternative hypothesis that the impact of the polymorphism is age-related and associated with late-onset obesity. We found, however, no evidence to support either hypotheses. Previously, an association has been reported [9] between the insertion-deletion heterozygote and increased estimates of sleeping metabolic rate, a variable which was not available for this study. Thus, we cannot exclude an impact of the 3 'UTR variant on this variable in our study. In contrast, we have had the opportunity to study the effect of the insertion-deletion variant on body weight gain. The BMI was measured in all subjects at the age of approximately 20 years and 46 years. The variant was, however, not associated with changes in BMI during a 26 year follow-up in any of the study groups. Therefore, it is concluded that the 3 'untranslated insertion variant of the $U C P 2$ gene does not have any major impact on the development of obesity in Danish Caucasian men. 
Acknowledgements. The authors thank A. Forman, L. Aabo and B. Mottlau for dedicated technical assistance, G. Lademann for secretarial support and S. Urhammer, MD, for helpful suggestions. The study was supported by the University of Copenhagen, the Velux Foundation, the Danish Medical Research Council, EEC grant (BMH4-CT-950662), the Danish Heart Foundation, the Foundation of Director Jacob Madsen and wife Olga Madsen and the Foundation of King Christian the $\mathrm{X}^{\text {th }}$

\section{References}

1. Fleury C, Neverova M, Collins S et al. (1997) Uncoupling protein-2: a novel gene linked to obesity and hyperinsulinemia. Nat Genet 15: 269-272

2. Warden CH, Fisler JS, Pace MJ et al. (1993) Coincidence of genetic loci for plasma cholesterol levels and obesity in a multifactorial mouse model. J Clin Invest 92: 773-779

3. Bouchard C, Pérusse L, Chagnon YC et al. (1997) Linkage between markers in the vicinity of the uncoupling protein 2 gene and resting metabolic rate in humans. Hum Mol Genet 6: 1887-1889

4. Surwit RS, Wang S, Petro AE et al. (1998) Diet-induced changes in uncoupling proteins in obesity-prone and obesity-resistant strains of mice. Proc Natl Acad Sci USA 95: 4061-4065
5. Nordfors L, Hoffstedt J, Nyberg B et al. (1998) Reduced gene expression of $U C P 2$ but not UCP3 in skeletal muscle of human obese subjects. Diabetologia 41: 935-939

6. Oberkopfler H, Liu YM, Esterbauer et al. (1998) Uncoupling protein-2 gene: reduced mRNA expression in intraperitoneal adipose tissue of obese humans. Diabetologia 41: 940-946

7. Otabe S, Clement K, Rich N et al. (1998) Mutation screening of the human UCP2 gene in normoglycemic and NIDDM morbidly obese patients. Diabetes 47: 840-842

8. Urhammer SA, Dalgaard LT, Sorenson TIA et al. (1997) Mutational analysis of the coding region of the uncoupling protein 2 gene in obese NIDDM patients: Impact of a common amino acid polymorphism on juvenile and maturity onset forms of obesity and insulin resistance. Diabetologia 40: $1227-1230$

9. Walder K, Norman RA, Hanson RL et al. (1998) Association between uncoupling protein polymorphisms (UCP2UCP3) and energy metabolism/obesity in Pima Indians. Hum Mol Genet 7: 1431-1435

10. Cassell PG, Neverova M, Janmohamed S et al. (1999) An uncoupling protein 2 gene variant is associated with a raised body mass index but not type II diabetes. Diabetologia 42: 688-692

11. Sonne-Holm S, Sorensen TIA, Jensen G et al. (1989) Independent effects of weight change and attained body weight on prevalence of arterial hypertension in obese and nonobese men. BMJ 299: 767-779 